\title{
Comparative studies of mononuclear phagocyte function in patients with Crohn's disease and colon neoplasms
}

\author{
W L BEEKEN, SUSAN ST ANDRE-UKENA, AND R MARY GUNDEL \\ From the Department of Medicine, University of Vermont, Burlington, Vermont, USA
}

SUMMARY Phagocytosis and cellular cytotoxicity by mononuclear phagocytes of blood and intestinal mucosa were studied in patients with Crohn's disease and large bowel neoplasms. Antibody coated sheep erythrocytes were used for phagocytic assays and cellular cytotoxicity in vitro was measured by 24 hour isotope release from ${ }^{75}$ Selenium methionine-labelled RPMI 4788 human cancer cell cultures in the presence of mononuclear phagocyte-enriched effector populations. The mean percent of mononuclear phagocytes in Ficoll-Hypaque purified mononuclear cell suspensions of blood of healthy controls was 25.9 compared with 44.6 in patients with Crohn's disease, 45.6 in patients with colon neoplasms and 11.6 in intestinal mucosa. Phagocytic indices were similar in all groups, but the phagocytic capacity of mucosal macrophages was twice that of blood monocytes. Mean cytotoxicity of monocytes of patients with Crohn's disease was $12.8 \%$ compared with $22.9 \%$ for monocytes from normal controls, and $29.4 \%$ for patients with colon tumours. Mean cytotoxicity by mucosal macrophages was $18.0 \%$ compared with $13.2 \%$ by mucosal lymphocyte populations. Exposure of monocytes of Crohn's disease patients to bacterial lipopolysaccharide modestly increased cytotoxicity, but exposure did not alter phagocytosis by monocytes of patients or controls. The results indicate that monocytes of patients with Crohn's disease exhibit subnormal in vitro cytotoxicity. Mucosal macrophages from patients with various diseases show enhanced phagocytosis compared with blood monocytes, and they can mediate cellular cytotoxicity in vitro.

Mononuclear phagocytes are a prominent part of the inflammatory response in Crohn's disease and certain neoplasms, but little is known of their function in these disorders. In Crohn's disease monocyte numbers in peripheral blood are increased ${ }^{1-4}$ and their turnover is faster. ${ }^{3} \mathrm{IgG}$ and $\mathrm{C}_{3}$ receptor activity, ${ }^{5}$ lysosomal enzyme concentrations, ${ }^{6-8}$ and secretion of plasminogen activator ${ }^{9}$ are also increased. Phagocytosis of Candida albicans ${ }^{10}$ and Staphylococcus aureus ${ }^{11}$ is augmented in Crohn's disease but intracellular killing of ingested organisms is not increased. In addition, monocytes may act as suppressors of natural killer cells in Crohn's disease. ${ }^{12}$

Mononuclear phagocytes are also of potential

Address for correspondence: W L Beeken, MD, C 311 Given Building. University of Vermont, Burlington VT, 05405 USA.

Received for publication 20 December 1982. relevance to patients with colonic neoplasms from the standpoint of immune surveillance ${ }^{13}$ and resistance to infection. ${ }^{14}$ Compared with normal subjects, patients with certain cancers have raised numbers of circulating mononuclear phagocytes, ${ }^{15}$ and macrophages are found in significant numbers within many tumours. ${ }^{16}$ Tumour macrophages are essential for antitumour cytotoxic responses in certain in vitro systems. ${ }^{17}$ In human mammary tumours and melanomas, where mononuclear phagocytes may account for as much as $30 \%$ of the tumour cell mass, the percentage of macrophages correlates inversely with metastasis. ${ }^{18}$

To explore the functional status of mononuclear phagocytes in Crohn's disease and colon neoplasms further, we studied phagocytosis and cellular cytotoxicity by these cells in peripheral blood and intestinal mucosa from patients with these disorders. 


\section{Methods}

The subjects studied are listed in Table 1 . Healthy controls had no evidence of gastrointestinal disease or intercurrent illness. Crohn's disease was documented by combined clinical, radiological, and histological criteria. According to Crohn's Disease Activity Indices, ${ }^{19}$ which ranged from 64 to 447 , eight patients had inactive disease and 12 had active disease. Nine patients were on no medication, seven were taking corticosteroids in varying doses, two were taking sulphasalazine, and two were taking azathioprine. In the colon neoplasia group, five patients had Dukes A, seven had Dukes B, and four had Dukes $C$ lesions. One patient had a large benign polyp. Intestinal mucosa was available for study from three patients with Crohn's disease, one with ulcerative colitis, one with angiodysplasia, and 10 with colonic neoplasms. All subjects gave informed consent according to the guidelines of the Human Experimentation Committee of the University of Vermont.

\section{MONONUCLEAR PHAGOCYTE ISOLATION}

Peripheral blood In patients having resections blood samples were removed immediately before surgery. Sixty millilitres of venous blood was collected in preservative free heparin $(10 \mathrm{U} / \mathrm{ml})$ and the mononuclear cells separated on FicollHypaque. ${ }^{20}$. Mononuclear cells were washed three times in chilled Hank's balanced salt solution and resuspended in tissue culture medium consisting of

Table 1 Subjects studied

\begin{tabular}{|c|c|c|c|c|c|}
\hline & \multirow[b]{2}{*}{$n$} & \multicolumn{4}{|c|}{ Peripheral blood } \\
\hline & & $\begin{array}{l}\text { Age } \\
\text { range }\end{array}$ & $M: F$ & $\begin{array}{l}\text { Phago- } \\
\text { cytosis } \\
n\end{array}$ & $\begin{array}{l}\text { Cyto- } \\
\text { toxicity } \\
n\end{array}$ \\
\hline Hcalthy controls & 20) & $25-58$ & $11: 9$ & 14 & 14 \\
\hline Crohn`s discase & 20 & $24-54$ & $9: 11$ & 11 & 12 \\
\hline \multirow[t]{3}{*}{ Colonic neoplasm } & 17 & $40-87$ & $8: 9$ & 13 & 12 \\
\hline & & \multicolumn{4}{|c|}{ Intestinal mucosa } \\
\hline & $n$ & \multicolumn{2}{|c|}{ Segment } & $\begin{array}{l}\text { Phago- } \\
\text { cytosis } \\
n\end{array}$ & $\begin{array}{l}\text { Cyto- } \\
\text { toxicity } \\
n\end{array}$ \\
\hline Crohn's discasc & 3 & \multicolumn{2}{|c|}{$\begin{array}{l}\text { Normal } \\
\text { ileum (2) } \\
\text { Abnormal } \\
\text { ilcum (1) }\end{array}$} & 1 & 3 \\
\hline $\begin{array}{l}\text { Ulcerative } \\
\text { colitis }\end{array}$ & 1 & \multicolumn{2}{|c|}{$\begin{array}{l}\text { Normal } \\
\text { right colon }\end{array}$} & 1 & 0 \\
\hline Angiodysplasia & 1 & \multicolumn{2}{|c|}{$\begin{array}{l}\text { Normal } \\
\text { right colon }\end{array}$} & 0 & 1 \\
\hline Colon neoplasm & 10 & \multicolumn{2}{|c|}{ Normal colon } & 8 & 4 \\
\hline
\end{tabular}

Eagle's minimum essential medium (MA Bioproducts, Walkersville, MD) containing $2 \mathrm{mM}$ L-glutamine, penicillin $(100 \mathrm{U} / \mathrm{ml})$, streptomycin $(100 \mathrm{mcg} / \mathrm{ml})$, and gentamicin $(50 \mathrm{mcg} / \mathrm{ml})$ and $10 \%$ heat inactivated fetal calf serum or autologous serum or plasma. Mononuclear cells were counted in a haemacytometer and viability was determined by trypan blue exclusion. The percentage of mononuclear phagocytes in the mononuclear cell population was determined from alpha napthylacetate esterase strains $^{21}$ of cytocentrifuge preparations.

Monocytes were separated from lymphocytes by adherence in $75 \mathrm{~cm}^{2}$ tissue culture flasks for $30-60$ minutes, the period determined to be optimal by time course adherence studies. Lymphocytes were removed by vigorous washing three times, and adherent mononuclear phagocytes were chilled on ice and removed by gentle scraping with a rubber policeman. Cells in the suspension were counted and cytocentrifuge preparations were stained for esterase to determine the percentage of monocytes.

Mucosal mononuclear phagocytes A modification of the method of Bull and Bookman ${ }^{22}$ was used to separate mononuclear cells from the intestinal mucosa for subsequent isolation of mucosal macrophages. Immediately after resection representative full thickness segments of intestine were immersed in chilled Hank's balanced salt solution containing antibiotics. Using sterile technique, the mucosa was dissected from the muscularis, extensively washed, weighed, and incubated for five minutes in Hank's balanced salt solution containing $1 \mathrm{mM}$ dithiothreitol and washed again in calcium-magnesium free Hank's balanced salt solution. Mucosa was then incubated for three 60 minute periods in $0.75 \mathrm{mM}$ EDTA to remove epithelial cells from the lamina propria. The exposed lamina propria was next incubated overnight in tissue culture medium containing $0.075 \mathrm{mg} / \mathrm{ml}$ collagenase (Type IV, Sigma Chemical Co, St Louis, MO, or CLSPA, Worthington Biochemical Corp, Freehold, NJ) at $37^{\circ} \mathrm{C}$ with gentle stirring. Mononuclear cells were filtered through a siliconised mesh, number 300 , and further purified on a Ficoll-Hypaque gradient. Cells were washed, aliquots removed for study, and the remaining mononuclear cells were transferred to tissue culture flasks for adherence of mononuclear phagocytes as detailed above. Viability of mucosal mononuclear cell suspensions routinely exceeded $85 \%$, and were usually above $90 \%$.

PHAGOCYTOSIS OF ANTIBODY COATED SHEEP ERYTHROCYTES

Phagocytosis by adhered cells $5 \times 10^{5}$ mononuclear 
phagocytes suspended in $0.5 \mathrm{ml}$ tissue culture medium (fetal calf serum) were spread evenly on plastic cover slips (Thermanox 1.5. Lux Scientific Corp, Newbury Park, CA) and incubated for one hour at $37^{\circ} \mathrm{C}$ in $5 \% \mathrm{CO}_{2}$. Adhered cells were rinsed with phosphate buffered saline and incubated for another hour with $0.5 \mathrm{ml}$ of IgG coated sheep erythrocytes (Cordis Laboratory, Miami, FL). Cover slips were immersed in distilled water for 20 seconds to lyse unphagocytosed erythrocytes, rinsed in phosphate buffered saline for five seconds, air dried, fixed, and stained for alpha napthylacetate esterase.

Phagocytosis by cell suspensions $5 \times 10^{5}$ cells per $0.5 \mathrm{ml}$ tissue culture medium (fetal calf serum) were mixed with $0.5 \mathrm{ml}$ of $\mathrm{IgG}$ coated erythrocytes in 15 $\mathrm{ml}$ test tubes and the suspensions were incubated at $37^{\circ} \mathrm{C}$ in $\mathrm{CO}_{2}$ for 60 minutes with frequent shaking. The suspensions were then centrifuged, the supernatants removed, and the pellets resuspended in $5 \mathrm{ml}$ ammonium chloride, $0.9 \%$, to lyse erythrocytes. Suspensions were again centrifuged, resuspended in tissue culture medium (fetal calf serum) and cytocentrifuge preparations were stained for alpha napthylacetate esterase.

Results of the phagocytosis studies were expressed as the percent of 100 or more mononuclear phagocytes showing erythrocyte ingestion (phagocytic index) and the mean number of erythrocytes ingested by 20 randomly selected mononuclear phagocytes (phagocytic capacity).

\section{CELLULAR CYTOTOXICITY}

Cytotoxicity assays were conducted with effector populations of mixed mononuclear cells (lymphocytes and mononuclear phagocytes, mononuclear cells) and adherent cells (mononuclear phagocyte-enriched, mononuclear phagocytes) in $10 \%$ fetal calf serum or autologous serum. Target cells were RPMI 4788 human colon cancer cells grown in tissue culture as adherent monolayers (kindly supplied by Dr M F Kagnoff, University of Californian, San Diego, La Jolla, CA). RPMI 4788 cells were labelled with ${ }^{75}$ seleno-methionine $\left({ }^{75} \mathrm{Se}\right.$ RPMI 4788) by washing in methionine-free Ham's solution, mixing with 50 to $100 \mu \mathrm{c}$ of ${ }^{75} \mathrm{Se}$ and incubating in Falcon Microtiter II plates for a 24 hour period in humidified $5 \% \mathrm{CO}_{2}$ at $37^{\circ} \mathrm{C}$. Labelled targets were washed three times and inoculated with medium alone and with suspensions of mononuclear cells and mononuclear phagocyte effector cell populations at effector:target ratios of 50 viable lymphocytes or mononuclear phagocytes per target cell. Cytotoxicity assays were done in quintuplicate except for several instances when a limited yield of effectors required they be done in triplicate or quadruplicate. Microtitre plates were incubated for four and 24 hours at $37^{\circ} \mathrm{C}$ in $5 \% \mathrm{CO}_{2}$, and the radioactivity in the supernatant solutions and in the target cell monolayers was determined. Cytotoxicity was calculated by the following equations:

Total percent release

$$
=\frac{\text { CPM supernatant }}{\text { CPM supernatant }+ \text { CPM cells }} \times 100
$$

Cytotoxicity

$\%$ release in test condition

$$
=\frac{-\% \text { spontaneous release }}{100-\% \text { spontaneous release }} \times 100
$$

Using cytospin values of \% mononuclear phagocytes in mononuclear cells populations, the \% mononuclear cell cytotoxicity due to mononuclear phagocyte effectors was calculated as follows:

$\%$ MNC cytotoxicity due to MP

$$
=\frac{\% \mathrm{MP} \text { cytotoxicity } \times \% \mathrm{MP} \text { in MNC }}{\% \mathrm{MNC} \text { cytotoxicity }}
$$

These calculations assumed that nonmononuclear phagocyte adherent cells were not cytotoxic. Thus values of mononuclear phagocyte cytotoxicity, mononuclear cell cytotoxicity and percent mononuclear cell cytototoxicity due to mononuclear phagocytes were available for comparison.

The effect of lipopolysaccharide (S. Typhosa 0901, Difco Laboratories, Detroit, MI) was evaluated in phagocytosis studies by preincubating mononuclear phagocytes in $50 \mathrm{ug} / \mathrm{ml}$ for 1 hour before exposure to antibody coated erythrocytes. The effect on cytotoxicity was assessed by addition of $50 \mathrm{ug} / \mathrm{ml}$ lipopolysaccharide during cytotoxicity assays.

Results were statistically analysed for significant differences by paired and unpaired Student's $t$ tests.

\section{Results}

The percentages of mononuclear phagocytes in whole mononuclear cell suspensions and adherent populations in various groups are given in Table 2. Mononuclear phagocytes comprised a significantly higher proportion of the mononuclear cell population in Crohn's disease and cancer patients compared with controls $(\mathrm{p}<0.001)$, but mucosal suspensions had significantly lower proportions of mononuclear phagocytes compared with normal blood $(p<0.01)$. The percentage of mononuclear phagocytes in adherent populations from mucosa was significantly lower than in blood of controls and Crohn's disease $(p<0.001)$. The esterase negative 
Table 2 Mean percentages \pm SEM of mononuclear phagocytes (MP) in mononuclear cell suspensions (MNC) and adherent populations.

\begin{tabular}{lllll}
\hline & $\begin{array}{l}\text { Control } \\
\text { blood }\end{array}$ & $\begin{array}{l}\text { Crohn's disease } \\
\text { blood }\end{array}$ & $\begin{array}{l}\text { Colon cancer } \\
\text { blood }\end{array}$ & $\begin{array}{l}\text { Intestinal } \\
\text { mucosa }\end{array}$ \\
\hline Percent MP in MNC & $25 \cdot 9 \pm 3 \cdot 9$ & $44 \cdot 6 \pm 4 \cdot 7$ & $45 \cdot 6 \pm 4 \cdot 3$ & $11 \cdot 6 \pm 2 \cdot 5$ \\
Percent MP in adherent population & $(13)$ & $(16)$ & $(14)$ & $(8)$ \\
& $(15)$ & $77 \cdot 9 \pm 4 \cdot 3$ & $64 \cdot 4 \pm 5 \cdot 5$ & $41 \cdot 1 \pm 9 \cdot 0$ \\
\end{tabular}

()$=$ number of subjects

adherent cells were presumably B-lymphocytes. ${ }^{23}$

The results of phagocytosis studies are given in Table 3. Phagocytic indices in suspensions were somewhat less than in adhered cells. The phagocytic capacity ranged from $2 \cdot 7$ to $4 \cdot 1$ in peripheral blood for all groups, and was nearly twice that for mucosal macrophages. Exposure of blood monocytes to lipopolysaccharide had no effect on either the phagocytic index or the phagocytic capacity in controls and patients with Crohn's disease.

Cytotoxicity of mononuclear phagocytes in four hour studies was minimal. Results of 24 hour assays are given in Tables 4 and 5 . Cytotoxicity was lowest in patients with Crohn's disease and highest in patients with colonic neoplasms. Cytotoxicity by mucosal mononuclear phagocytes was similar to that of monocyte-enriched preparations of peripheral blood of healthy subjects, and was actually greater than cytotoxicity of mononuclear cells. Results in fetal calf serum and autologous serum were similar. Mean cytotoxicity by mixed mononuclear cell populations (lymphocytes and mononuclear phagocytes) was $42.2 \%$ for healthy controls, $22.3 \%$ for patients with Crohn's disease, $30.7 \%$ for patients with colon carcinoma and $13.3 \%$ for intestinal mucosa. Assuming that the only cytotoxic cells in the adherent populations were mononuclear phagocytes, the remainder being non-cytotoxic Bcells, ${ }^{23}$ the percentages of cytotoxicity of mixed mononuclear cells populations attributable to mononuclear phagocytes were $15,27,44$ and 31 for controls, Crohn's disease, cancer and intestinal mucosa respectively. The percentage in cancer patients was significantly higher than for controls $(\mathrm{p}<0.001)$.

Lipopolysaccharide had a modest stimulatory effect on cytotoxicity by blood monocytes of patients with Crohn's disease, but did not increase monocyte cytotoxicity of healthy controls. (Table 6.)

\section{Discussion}

These studies are consistent with previous observations of increased numbers of mononuclear phagocytes in patients with Crohn's disease and document similar changes in patients with colon neoplasms. We also confirm that mononuclear phagocytes comprise approximately $10 \%$ of the mononuclear population of the lamina propria of

Table 3 Results of phagocytic studies

\begin{tabular}{|c|c|c|c|c|}
\hline & $\begin{array}{l}\text { Control } \\
\text { blood }\end{array}$ & $\begin{array}{l}\text { Crohn's disease, } \\
\text { blood }\end{array}$ & $\begin{array}{l}\text { Colon cancer } \\
\text { blood }\end{array}$ & $\begin{array}{l}\text { Intestinal } \\
\text { mucosa }\end{array}$ \\
\hline Phagocytic index - suspension & $\begin{array}{l}87 \cdot 6 \pm 2 \cdot 0 \\
(14)\end{array}$ & $\begin{array}{l}85 \cdot 5 \pm 8 \cdot 0 \\
(11)\end{array}$ & $\begin{array}{l}86 \cdot 3 \pm 2 \cdot 4 \\
(10)\end{array}$ & $\begin{array}{l}67 \cdot 6 \pm 8 \cdot 7 \\
(6)\end{array}$ \\
\hline Phagocytic index — adhered & $\begin{array}{l}92 \cdot 7 \pm 1 \cdot 4 \\
(14)\end{array}$ & $\begin{array}{l}89 \cdot 8 \pm 3 \cdot 3 \\
(11)\end{array}$ & $\begin{array}{l}94 \cdot 0 \pm 1 \cdot 0 \\
(13)\end{array}$ & $\begin{array}{l}87 \cdot 6 \pm 6 \cdot 0 \\
(10)\end{array}$ \\
\hline Phagocytic index - adhered + LPS & $\begin{array}{l}90 \cdot 0 \pm 3 \cdot 1 \\
(9)\end{array}$ & $\begin{array}{l}91 \cdot 1 \pm 3 \cdot 3 \\
(7)\end{array}$ & & \\
\hline Phagocytic capacity - suspension & $\begin{array}{l}3 \cdot 1 \pm 0 \cdot 2 \\
(14)\end{array}$ & $\begin{array}{l}2 \cdot 7 \pm 0 \cdot 3 \\
(11)\end{array}$ & $\begin{array}{l}3 \cdot 6 \pm 0 \cdot 3 \\
(13)\end{array}$ & $\begin{array}{l}5 \cdot 5 \pm 1 \cdot 0 \\
(6)\end{array}$ \\
\hline Phagocytic capacity - adhered & $\begin{array}{l}3 \cdot 7 \pm 0 \cdot 2 \\
(14)\end{array}$ & $\begin{array}{l}3 \cdot 2 \pm 0 \cdot 2 \\
(11)\end{array}$ & $\begin{array}{l}4 \cdot 11 \pm 0 \cdot 2 \\
(13)\end{array}$ & $\begin{array}{l}8 \cdot 1 \pm 0 \cdot 7 \\
(10)\end{array}$ \\
\hline Phagocytic capacity - adhered + LPS & $\begin{array}{l}3 \cdot 3 \pm 0 \cdot 03 \\
(9)\end{array}$ & $\begin{array}{l}3 \cdot 4 \pm 0 \cdot 4 \\
(7)\end{array}$ & & \\
\hline
\end{tabular}

Phagocytic index $=$ percent of mononuclear phagocytes ingesting erythrocytes. Phagocytic capacity $=$ number of erythrocytes ingested per mononuclear phagocyte. LPS = lipopolysaccharide. ()$=$ number of subjects studied.

Results are means \pm SEM. 
Table 4 Results of 24 hour cytotoxicity studies

\begin{tabular}{lllll}
\hline & $\begin{array}{l}\text { Control } \\
\text { blood }\end{array}$ & $\begin{array}{l}\text { Crohn's disease } \\
\text { blood }\end{array}$ & $\begin{array}{l}\text { Colon cancer } \\
\text { blood }\end{array}$ & $\begin{array}{l}\text { Intestinal } \\
\text { mucosa }\end{array}$ \\
\hline MP cytotoxicity & $22 \cdot 9 \pm 6 \cdot 3$ & $12 \cdot 8 \pm 4 \cdot 1$ & $29 \cdot 4 \pm 8 \cdot 3$ & $18 \cdot() \pm 5 \cdot 2$ \\
MNC cytotoxicity & $(14)$ & $(14)$ & $(12)$ & $(8)$ \\
Percent MNC cytotoxicity due to MP & $42 \cdot 2 \pm 10 \cdot 7$ & $22 \cdot 3 \pm 4 \cdot 3$ & $30 \cdot 7 \pm 5 \cdot 5$ & $13 \cdot 2 \pm 4 \cdot 2$ \\
& $(12)$ & $(15)$ & $(12)$ & $(8)$ \\
& $15 \cdot 0 \pm 3 \cdot 0$ & $27 \cdot 0 \pm 6 \cdot 8$ & $43 \cdot 9 \pm 7 \cdot 7$ & $31 \cdot 0 \pm 16 \cdot 2$ \\
\hline
\end{tabular}

Means \pm standard errors of the means.

$\mathrm{MP}=$ mononuclear phagocyte $\mathrm{MNC}=$ mononuclear cell $($ () = number studied.

the distal human intestine. In this study a significant number of adherent cells were esterase negative and therefore did not qualify as mononuclear phagocytes. Extrapolating from animal studies these cells were presumably B-lymphocytes, and thus were neither cytotoxic nor phagocytic. The consistently lower phagocytic index in suspensions, especially in mucosal suspensions, is unexplained, but could indicate altered $\mathrm{Fc}$ receptor function in a subgroup of the mononuclear phagocytes population. The phagocytic capacity of circulating monocytes of all study groups was similar, but a significantly higher phagocytic capacity was found in mucosal macrophages. These cells were apparently stimulated or activated within the intestinal mucosa. Among many potential mediators to which mucosal macrophages are exposed, lipopolysaccharide would be expected to be important. Despite contrary results in animal studies, ${ }^{24}$ however, under the conditions of our studies, lipopolysaccharide had no effect on phagocytic function of blood monocytes of controls and Crohn's disease patients.

The lowest cytotoxicity values occurred in mononuclear phagocytes and mononuclear cell effectors of blood from patients with Crohn's disease, and in mononuclear cells of intestinal mucosa. The highest values occurred in mononuclear phagocytes from patients with colonic neoplasms. The subnormal cytotoxicity of mononuclear phagocytes in Crohn's disease may be related to rapid monocyte turnover and resulting immaturity, but purified human monocytes reportedly lose their cytotoxic capability during maturation in vitro. ${ }^{25}$ Cytotoxicity was minimal at four hours and unheated autologous serum was not cytotoxic, indicating that the observed cytotoxicity was not an antibody mediated process. ${ }^{26-28}$ Thus we surmise that cell lysis occurred by non-specific cell mediated cytotoxicity. It is known that human monocytes effect cytotoxicity by spontaneous cell mediated mechanisms, ${ }^{29}$ as well as by antibody dependent cellular cytotoxicity, ${ }^{25} 29$ and by

Table 5 Percent cytotoxicity of mucosal and blood mononuclear cell (MNC) and mononuclear phagocyte (MP) effectors. Assays conducted in $10 \%$ fetal calf serum at effector:target ratios of 50 lymphocytes per target for MNC and 50 esterase positive macrophages per target for $M P$

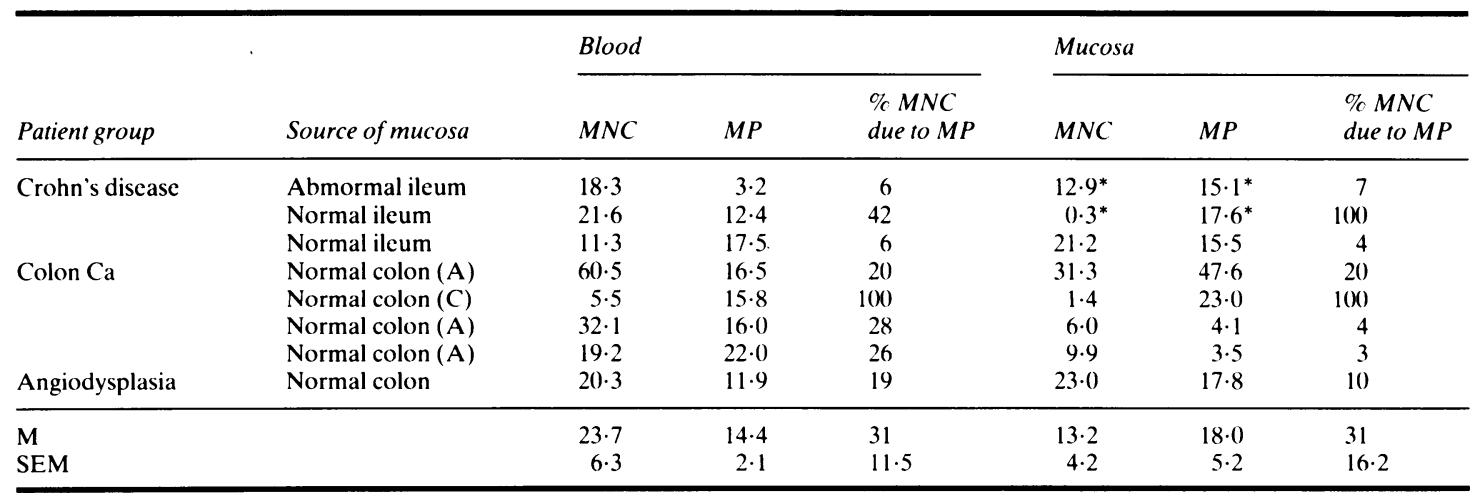

* Conducted in autologous serum.

$\mathrm{M}=$ mean: $\mathrm{SEM}=$ standard error of the mean. ()$=$ Dukes classification. 
Table 6 Effect of lipopolysaccharide (LPS) on 24 hour cytotoxicity by mononuclear cells (MNC) and mononuclear phagocytes (MP) of patients with Crohn's disease and controls matched for age and sex

\begin{tabular}{|c|c|c|c|c|}
\hline & \multicolumn{4}{|c|}{ Matched control } \\
\hline & \multicolumn{2}{|l|}{$A S$} & \multicolumn{2}{|c|}{$A S+L P S$} \\
\hline & $M N C$ & $M P$ & $M N C$ & $M P$ \\
\hline \multicolumn{5}{|c|}{ Subject } \\
\hline 1 & $13 \cdot 1$ & $11 \cdot 4$ & $53 \cdot 7$ & $2 \cdot 0$ \\
\hline 2 & $117 \cdot 3$ & $70 \cdot 6$ & $89 \cdot 1$ & $54 \cdot 8$ \\
\hline 3 & $73 \cdot 9$ & $18 \cdot 8$ & $85 \cdot 1$ & 18.0 \\
\hline 4 & $36 \cdot 8$ & $11 \cdot 6$ & $67 \cdot 4$ & $16 \cdot 6$ \\
\hline 5 & $83 \cdot 0$ & $72 \cdot 6$ & 99.0 & $77 \cdot 0$ \\
\hline $\mathbf{M}$ & $64 \cdot 8$ & $37 \cdot 0$ & 78.9 & 33.7 \\
\hline \multirow[t]{2}{*}{ SEM } & $20 \cdot 4$ & $15 \cdot 9$ & $9 \cdot 1$ & $15 \cdot 5$ \\
\hline & \multicolumn{4}{|c|}{ Crohn's disease } \\
\hline 1 & $11 \cdot 7$ & $5 \cdot 5$ & $15 \cdot 0$ & $5 \cdot 5$ \\
\hline 2 & $25 \cdot 3$ & $9 \cdot 3$ & $44 \cdot 5$ & 10.5 \\
\hline 3 & $22 \cdot 8$ & 4.6 & $26 \cdot 9$ & 9.8 \\
\hline 4 & $11 \cdot 1$ & $3 \cdot 4$ & $21 \cdot 7$ & $7 \cdot 0$ \\
\hline 5 & $19 \cdot 5$ & $5 \cdot 5$ & $20 \cdot 1$ & $13 \cdot 8$ \\
\hline M & $18 \cdot 1$ & $5 \cdot 7$ & $25 \cdot 6$ & $9 \cdot 3$ \\
\hline SEM & $3 \cdot 2$ & $1 \cdot 1$ & $5 \cdot 7$ & 1.6 \\
\hline
\end{tabular}

AS $=$ autologous serum or plasma $. \mathbf{M}=$ mean. $S E M=$ standard error of the mean.

augmentation of lymphocyte cytotoxicity for adherent targets. ${ }^{30}$ Lymphokines $^{31}$ and lipopolysaccharide ${ }^{30-33}$ enhance cytotoxicity by mononuclear phagocytes. In man, hydrocortisone and acetylsalicyclic acid reportedly augment monocyte cytotoxicity, ${ }^{34}$ but corticosteroids inhibit cytotoxicity of interferon stimulated peritoneal macrophages of mice. ${ }^{35}$ Animal studies also indicate that spontaneous cytotoxicity by natural killer cells is inhibited by starvation, ${ }^{36}$ but this important aspect has not been examined using human mononuclear phagocytes. All of these factors could be influencing the cytotoxicity observed in this study, and further investigations will be required to obtain a better understanding of these events.

These studies also show that adherent mucosal macrophages are capable of effecting cytotoxicity for colon cancer cells grown in culture. In both blood and mucosa mononuclear phagocytes were calculated to account for approximately $30 \%$ of the cytotoxic capacity of mixed mononuclear cell effectors. Adherent mucosal macrophages were often more cytotoxic than the corresponding mucosal mononuclear populations and the circulating monocytes of the same patient. The small numbers of resections from which macrophage cytotoxicity data were available, and the diverse sources preclude any conclusions regarding altered functions in specific patient groups, Moreover, the mononuclear phagocyte populations contained esterase negative mononuclear cells, and the methods used did not permit direct assay of cytotoxicity by non-adherent mononuclear phagocytes of mucosa. New techniques for isolating purer populations of mononuclear phagocytes have been reported, ${ }^{25}$ and the application of these methods will be of great advantage in future studies of macrophages of intestinal mucosa.

In conclusion, we confirm the increase of mononuclear phagocytes in peripheral blood of patients with Crohn's disease and document similar findings in colonic cancer. Mononuclear phagocytes comprise approximately $10 \%$ of the mononuclear cell population of human intestinal mucosa. This value is one-fourth that found in blood of patients with Crohn's disease and colon cancer and one-half that found in healthy subjects. Phagocytosis by circulating monocytes of the various study groups was similar, but mucosal macrophages ingested significantly more opsonised erythrocytes. Adherent mononuclear phagocytes of blood of normal subjects and colon cancer patients and adherent mucosal macrophages showed active cytotoxicity for neoplastic epithelial cells in vitro. Cytotoxicity by blood mononuclear phagocytes in patients with Crohn's disease was subnormal, coinciding with similar defects reported for natural killer cells in these patients. ${ }^{12}$ Lipopolysaccharide had little effect on phagocytes of patients with Crohn's disease. Further studies of these functional differences in Crohn's disease and colon cancer are needed to determine if these changes could be involved in the pathogenesis of these disorders.

This study was supported by PHS Grants AM 21564 and S07 05429-20 and General Clinical Research Centers Grant RR 109. Jennifer Penhallow provided expert typing assistance.

\section{References}

1 Thayer WR, Charland C, Field C. Subpopulations of circulating white blood cells in inflammatory bowel disease. Gastroenterology 1976; 71: 379-84.

2 Mee AS, Berney J, Jewell DP. Monocytes in inflammatory bowel disease: absolute monocyte counts. J Clin Pathol 1980; 33: 917-20.

3 Meuret G, Bitzi A, Hammer B. Macrophage turnover in Crohn's disease and ulcerative colitis. Gastroenterology 1978; 74: 501-3. 
4 Auer IO, Wechsler W, Ziemer E, Malchow H, Sommer $\mathrm{H}$. Immune status in Crohn's disease. I. Leukocyte and lymphocyte subpopulations in peripheral blood. Scand J Gastroenterol 1978; 13: 561-71.

5 Schmidt M. Douglas S. Monocyte IgG receptor activity dynamics and modulation - normal individuals and patients with granulomatous diseases. $J$ Lab Clin Med 1977; 89: 332-40.

6 Mee AS, Jewell DP. Monocytes in inflammatory bowel disease: monocyte and serum lysosomal enzyme activity. Clin Sci 1980; 58: 295-300.

7 Ganguly NK. Lloyd B, Price CP et al. Acid hydrolases in monocytes from patients with inflammatory bowel disease, chronic liver disease and rheumatoid arthritis. Lancet 1978; 1: 1073-5.

8 Doe WF, Temple C, Dorsman B, Golder J. Monocyte function in chronic inflammatory bowel disease. I. Lysosomal enzyme activity. Aust NZ J Med 1980; 10: 367.

9 Doe WF, Dorsman B, Temple C, Golder J. Monocyte function in chronic inflammatory bowel disease. Aust NZ J Med 1980; 10: 368.

10 Whorwell PJ, Bennett P, Tanner AR, Wright R. Monocyte function in Crohn's disease and ulcerative colitis. Digestion 1981; 22: 271-5.

11 Mee AS, Szawatakowski M, Jewell DP. Monocytes in inflammatory bowel disease: phagocytosis and intracellular killing. J Clin Pathol 1980; 33: 921-5.

12 Auer IO, Ziemer E, Sommer H. Immune status in Crohn's disease. V. Decreased in vitro natural killer cell activity in peripheral blood. Clin Exp Immunol 1980; 42: 41-9.

13 Hibbs JB, Chapman HA, Weinberg JB. The macrophage as an antineoplastic surveillance cell: biological perspectives. J Reticuloendothelial Soc 1978; 24: 54970 .

14 Estevez M. Fen L, Bachman AE, Pavlovsky A. Effective function of peripheral blood monocytes in patients with Hodgkin's disease and non-Hodgkin's lymphoma. Cancer 1980; 46: 299-302.

15 Wood GW, Neff JR. A reevaluation of B-lymphocyte levels in peripheral blood from cancer patients. $J$ Natl Cancer Inst 1978; 61: 715-8.

16 Wood GW, Gollahon KA. Detection and quantitation of macrophage infiltration into primary human tumors with use of cell surface markers. $J$ Natl Cancer Inst 1977; 59: 1081-7.

17 Woodward JG, Daynes RA. Cell mediated immune response to synergistic UV-induced tumors. Cell Immunol 1978; 41: 304-19.

18 Alexander P, Eccles SA, Gauci CLL. The significance of macrophages in human and experimental tumors. Ann NY Acad Sci 1976; 276: 124-33.

19 Best WR, Becktel JM, Singleton JW, Kern F. Development of a Crohn's disease activity index. Gastroenterology 1976; 70: 439-44.

20 Boyum A. Isolation of lymphocytes, granulocytes and macrophages. Scand J Immunol 1976; 5: (suppl) 15.

$21 \mathrm{Li}$ CY, Yam LT, Crosby WH. Histochemical characterization of cellular and structural element of human spleen. J Histochem Cytochem 1972; 20: 104958.

22 Bull DM, Bookman MA. Isolation and functional characterization of human intestinal mucosal lymphoid cells. J Clin Invest 1977; 59: 966-74.

23 Nathan CF, Asofsky R, Terry WD. Characterization of the nonphagocytic adherent cell from the peritoneal cavity of normal and BCG treated mice. J Immunol 1977; 118: 1612-21.

24 Schubert RD. David JR. Stimulation of guinea pig macrophage pinocytosis by lipopolysaccharide (LPS): evidence that LPS acts directly on the macrophage. Cell Immunol 1980; 55: 166-73.

25 Stevenson HC, Katz P, Wright DG et al. Human blood monocytes: characterization of negatively selected human monocytes and their suspension cell culture derivatives. Scand J Immunol 1981; 14: 243-56.

26 Nelson DL, Bundy BM, Strober W. Spontaneous cell-mediated cytotoxicity by human peripheral blood lymphocytes in vitro. J Immunol 1977: 119: 1401-5.

27 Russel JH, Masakowski VR, Dobos CB. Mechanisms of immune lysis. I. Physiological distinction between target cell death mediated by cytotoxic $\mathrm{T}$ lymphocytes and antibody plus complement. J Immunol 1980; 124: $1100-5$.

28 Sanderson CJ. Thomas JA. The mechanism of K cell (antibody-dependent) cell mediated cytotoxicity. I. The release of different cell components. Proc Roy Soc Lond B 1977; 197: 407-15.

29 Horwitz DA, Kight N. Temple A, Allison AC. Spontaneous and induced cytotoxic properties of human adherent mononuclear cells. Killing of nonsensitized and antibody-coated non-erythroid cells. Immunology 1979; 36: 221-8.

30 DeVries JE, Mendelsohn J, Bont WS. Requirement for monocytes in the spontaneous cytotoxic effects of human lymphocytes against non-lymphoid target cells. Nature 1980; 283: 574-6.

31 Cameron D, Churchill WH. Cytotoxicity of human macrophages for tumor cells. J Clin Invest 1979; 63: 977-84.

32 Doe WF, Henson PM. Macrophage stimulation by bacterial lipopolysaccharides. I. Cytolytic effect on tumor target cells. J Exp Med 1978; 148: 544-56.

33 Taramelli D, Holden HT, Varesio L. In vitro induction of tumoricidal and suppressor macrophages by lymphokines: possible feedback regulation. J Immunol 1981; 126: $2123-8$.

34 Kleinerman ES, Lovie JS, Wahl LM, Muchmore AV. Pharmacology of human spontaneous monocyte mediated cytotoxicity. I. Enhancement by salicylates and steroids. Arthritis Rheumatism 1981; 24: 774-80.

35 Schultz RM, Chirigos MA, Stoychkov JN, Pavlidis NA. Factors affecting macrophage cytotoxic activity with particular emphasis on corticosteroids and acute stress. J Reticuloendothelial Soc 1979; 26: 83-92.

36 Saxena RK, Saxena QB. Adler WH. Regulation of natural killer activity during starvation. Indian $J$ Exp Biol 1980; 18: 1383-6. 